\section{BMJ Open Ophthalmology}

\title{
Long-term clinical outcomes of keratoplasty using gamma-irradiated corneal lenticules
}

\author{
Priya M Mathews, ${ }^{1}$ Rajesh Fogla, ${ }^{2}$ Erik Samayoa, ${ }^{3}$ Shanna VanCourt, ${ }^{1}$ \\ Esen K Akpek (1) ${ }^{1}$
}

To cite: Mathews PM, Fogla R, Samayoa E, et al. Longterm clinical outcomes of keratoplasty using gammairradiated corneal lenticules. BMJ Open Ophthalmology 2019;4:e000396. doi:10.1136/ bmjophth-2019-000396

- Additional material is published online only. To view please visit the journal online (http://dx.doi.org/10.1136/ bmjophth-2019-000396).

Received 24 September 2019 Revised 15 October 2019 Accepted 16 October 2019

\section{Check for updates}

(C) Author(s) (or their employer(s)) 2019. Re-use permitted under CC BY-NC. No commercial re-use. See rights and permissions. Published by BMJ.

${ }^{1}$ Cornea and External Diseases, Wilmer Eye Institute, Johns Hopkins University School of Medicine, Baltimore, Maryland, USA

${ }^{2}$ Cornea Clinic, Apollo Hospitals, Hyderabad, India

${ }^{3}$ Hospital de la Familia, Nuevo

Progreso, Guatemala

Correspondence to Dr Esen KAkpek; esakpek@ jhmi.edu

\section{ABSTRACT}

Objective To report long-term clinical outcomes of gamma-irradiated corneal lenticules in partial and fullthickness keratoplasty.

Methods and Analysis This multicentre, retrospective case series includes 23 patients who underwent surgery at three centres (India, Guatemala, and USA) between May 2009 and March 2018. The main outcome measures were epithelialization and retention for therapeutic keratoplasty and best spectacle-corrected visual acuity (BSCVA) for optical keratoplasty.

Results Patients were categorised according to primary aetiology requiring corneal transplantation: non-inflammatory conditions, infectious keratitis and sterile keratolysis. Nine patients with non-inflammatory conditions underwent anterior lamellar keratoplasty $(n=7)$ and Boston type 1 keratoprosthesis $(n=2)$. All nine grafts remained intact and epithelialized during follow-up (median 24 months). In the seven patients who underwent anterior keratoplasty, the graft stayed optically clear during follow-up (median 12 months), with BSCVA between 20/20 and 20/40 in all but one patient who developed cataract. Nine patients with severe infectious keratitis had emergency patch grafting. Six of those grafts epithelialized and remained intact over a median of 30 months, providing tectonic support until optical keratoplasty with fresh tissue could be performed. Three grafts had recurrent infectious keratitis 1-3 months postoperatively, two of which underwent tectonic keratoplasty with fresh tissue which also eventually became infected during follow-up. In five additional patients with sterile keratolysis who underwent lamellar patch graft, two grafts remained intact during follow-up (median 36 months). Two patients had recurrent corneal melt within 1 month, and both had subsequent corneal surgery with fresh tissue which also failed. There were no donor-related complications.

Conclusion Gamma-irradiated sterile corneal stromal Ienticules can be considered as a viable alternative to fresh tissue in various clinical settings.

\section{INTRODUCTION}

Loss of corneal clarity is the fourth leading cause of blindness globally, following cataract, glaucoma and age-related macular degeneration. ${ }^{1}$ An estimated 10 million individuals are blind bilaterally due to various corneal conditions. ${ }^{2}$ Although keratoplasty remains

\section{Key messages}

What is already known about this subject?

- Gamma-irradiated corneal tissue, a decellularised, stromal collagen matrix, is a terminally sterilized tissue that can last for 2 years at room temperature.

This tissue is currently frequently used in glaucoma surgery; however, it has been used successfully for corneal patch grafts and anterior lamellar keratoplasty as well.

\section{What are the new findings?}

- This multicentre, retrospective case series demonstrates that gamma-irradiated corneal lenticules can be used for a variety of corneal diseases, including infectious, inflammatory (ie, autoimmune corneal melt) and non-inflammatory (ie, keratoconus) aetiologies.

- Additionally, this tissue can be used for therapeutic penetrating keratoplasty for full-thickness/perforating disease and optical keratoplasty for anterior lamellar keratoplasty.

\section{How might these results change the focus of research or clinical practice? \\ - Currently there is a significant unmet need for cor- nea around the world, with only one cornea available for every 70 patients. \\ - Gamma-irradiated corneal tissue is one way to ad- dress the severe shortage of fresh corneal tissue, particularly in areas that are less developed and with limited resources. \\ - The sterile cornea could be used for both therapeutic intervention (to restore the anatomy of the eyeball in the setting of trauma or perforation) and optica keratoplasty (to improve vision in patients with func- tioning endothelium).}

the most frequently performed transplant surgery in the world, the demand still far exceeds the supply. Regrettably currently about $53 \%$ of the world's population lack access to corneal transplantation. ${ }^{3}$ In order to overcome this, efforts to encourage eye banking must continue worldwide, but it is also essential to develop alternative solutions.

VisionGraft (KeraLink International, Baltimore, Maryland) is a decellularised stromal 


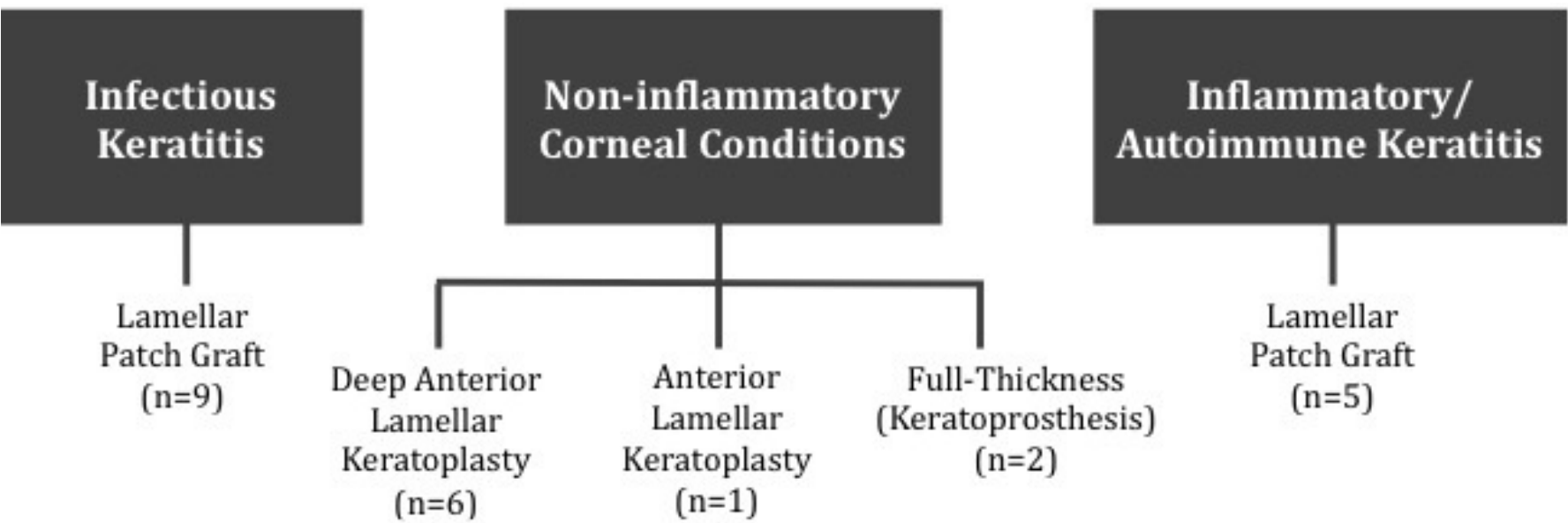

Figure 1 Type of surgery performed using gamma-irradiated corneal lenticules categorised by aetiology of corneal disease. This diagram displays the classification of all 23 patients, first by etiology of corneal disease and then by the surgical procedure performed.

collagen matrix. ${ }^{4-6}$ The harvested corneal donors with clear, uncompromised stroma that do not meet the criteria specified by the Medical Standards of the Eye Bank Association of America for full-thickness penetrating keratoplasty are gamma-irradiated and terminally sterilised for long-term preservation. Thus far, this tissue has been used mainly as a patch for glaucoma devices ${ }^{7}$ and tectonic corneal surgeries ${ }^{5}$ with good tissue integration and clarity. Two prior small case series demonstrated no donor-related complications when it was used full thickness as a carrier for Boston type 1 keratoprosthesis (KPro) transplantation. ${ }^{89}$

A review of published literature demonstrates that the physical and biological properties of the sterile cornea remain unaltered. ${ }^{10-12}$ Importantly, light transmission properties of this tissue have been found identical to fresh corneas across all wavelengths. ${ }^{6}$ Therefore, performance of sterile donor lenticules should be comparable with fresh corneal tissue if used for lamellar corneal procedures that do not require a viable endothelium. Additionally, the process of gamma irradiation reduces allogenicity of the tissue and may increase resistance to keratolysis by collagenases and reduce likelihood of allogeneic sensitisation. ${ }^{13}$ These properties are particularly advantageous in patients with autoimmune conditions or if there is a high likelihood of repeat keratoplasty in the future (ie, emergency therapeutic keratoplasty prior to optical keratoplasty). Therefore, gamma-irradiated corneal stromal tissue could be used for optical purposes in patients with viable corneal endothelium, or for therapeutic/tectonic purposes to temporise the full-thickness corneal disease. The purpose of this study was to report the long-term clinical outcomes of various uses of gammairradiated corneal stromal lenticules for keratoplasty.

\section{MATERIALS AND METHODS}

Subjects

Six patients who were noted to be candidates for deep anterior lamellar keratoplasty (DALK) surgery were recruited from Apollo Hospitals (Hyderabad, India) between September 2014 and November 2015. Patients had significant anterior stromal pathology with normal endothelium and ocular surface.

Two patients who presented with frank corneal perforation due to presumed infectious keratitis following trauma in March 2018 were included from Hospital de la Familia (Nuevo Progreso, Guatemala).

Fifteen patients were recruited from Wilmer Eye Institute (Johns Hopkins University, Baltimore, Maryland) between May 2009 and July 2016. The aetiology of corneal disease included non-inflammatory corneal conditions, infectious keratitis or autoimmune/inflammatory keratitis.

All patients were explained the risks and benefits of the surgery in detail prior to the procedure, as well as the use of gamma-irradiated tissue for corneal transplantation.

\section{Gamma-irradiated corneal tissue}

The gamma-irradiated corneal tissue is categorised as HCT/P (human cells, tissues, and cellular and tissuebased products); therefore, it is regulated in the same way as standard corneal tissue in the USA. The tissue is first recovered from medically qualified donors, following the standards and criteria established by the Eye Bank Association of America. The tissues not acceptable for penetrating keratoplasty, but with clear stroma, are selected for gamma irradiation and frozen for preservation and storage. For sterilisation process, the tissues are removed from the freezer and submerged in a storage medium containing human serum albumin. This sealed container is sterilised with a validated gamma irradiation process to a sterility assurance level of $10^{-6}$ per the American National Standard Sterilization of Health Care Products. ${ }^{5}$ These tissues are approved to be stored in the human serum albumin at room temperature for up to 2 years. All tissues used in this study were prepared in the USA and sent directly to each respective location. 
Table 1 Baseline demographics of patients who underwent partial or full-thickness keratoplasty using gamma-irradiated corneal lenticules

\begin{tabular}{|c|c|c|c|c|c|c|c|}
\hline Etiology & Patient & Country & Age (years) & Sex & Indication for surgery & Surgery & $\begin{array}{l}\text { Duration of } \\
\text { follow-up } \\
\text { (months) }\end{array}$ \\
\hline \multirow{9}{*}{$\begin{array}{l}\text { Non-inflammatory } \\
\text { corneal conditions }\end{array}$} & 1 & India & 22 & Male & Macular dystrophy & DALK & 24 \\
\hline & 2 & India & 52 & Female & Granular dystrophy & DALK & 12 \\
\hline & 3 & India & 22 & Female & Keratoconus & DALK & 12 \\
\hline & 4 & India & 28 & Female & Keratoconus & DALK & 24 \\
\hline & 5 & India & 33 & Female & Macular dystrophy & DALK & 24 \\
\hline & 6 & India & 24 & Male & Keratoconus & DALK & 12 \\
\hline & 7 & USA & 56 & Female & Multiple failed PKs & KPro & 39 \\
\hline & 8 & USA & 13 & Female & Limbal dermoid & ALK & 12 \\
\hline & 9 & USA & 74 & Female & Multiple failed PKs & KPro & 84 \\
\hline \multirow[t]{9}{*}{ Infectious keratitis* } & 10 & Guatemala & 43 & Female & $\begin{array}{l}\text { Presumed infectious } \\
\text { keratitis }\end{array}$ & LPG & 6 \\
\hline & 11 & Guatemala & 47 & Male & $\begin{array}{l}\text { Presumed infectious } \\
\text { keratitis }\end{array}$ & LPG & 6 \\
\hline & 12 & USA & 65 & Female & $\begin{array}{l}\text { Presumed herpetic } \\
\text { keratitis }\end{array}$ & LPG & 105 \\
\hline & 13 & USA & 65 & Male & Bacterial keratitis & LPG & 5 \\
\hline & 14 & USA & 48 & Female & $\begin{array}{l}\text { Presumed herpetic } \\
\text { keratitis }\end{array}$ & LPG & 30 \\
\hline & 15 & USA & 81 & Female & $\begin{array}{l}\text { Presumed herpetic } \\
\text { keratitis }\end{array}$ & LPG & 6 \\
\hline & 16 & USA & 51 & Female & $\begin{array}{l}\text { Presumed herpetic } \\
\text { keratitis with bacterial } \\
\text { superinfection }\end{array}$ & LPG & 100 \\
\hline & 17 & USA & 80 & Female & $\begin{array}{l}\text { Presumed herpetic } \\
\text { keratitis with fungal } \\
\text { superinfection }\end{array}$ & LPG & 91 \\
\hline & 18 & USA & 44 & Female & $\begin{array}{l}\text { Presumed herpetic } \\
\text { keratitis with bacterial } \\
\text { superinfection }\end{array}$ & LPG & 55 \\
\hline \multirow[t]{5}{*}{$\begin{array}{l}\text { Inflammatory/ } \\
\text { autoimmune } \\
\text { keratitis }^{*}\end{array}$} & 19 & USA & 80 & Female & $\begin{array}{l}\text { Systemic lupus } \\
\text { erythematosus with } \\
\text { secondary Sjögren's } \\
\text { syndrome }\end{array}$ & LPG & 96 \\
\hline & 20 & USA & 81 & Female & Rheumatoid arthritis & LPG & 53 \\
\hline & 21 & USA & 32 & Male & $\begin{array}{l}\text { Sterile keratolysis with } \\
\text { unknown aetiology }\end{array}$ & LPG & 36 \\
\hline & 22 & USA & 75 & Female & $\begin{array}{l}\text { Sterile keratolysis with } \\
\text { unknown aetiology }\end{array}$ & LPG & 29 \\
\hline & 23 & USA & 13 & Female & $\begin{array}{l}\text { Sterile inflammatory } \\
\text { corneal lesion with } \\
\text { unknown aetiology }\end{array}$ & LPG & 8 \\
\hline
\end{tabular}

${ }^{*}$ All patients with infectious and inflammatory/autoimmune aetiology had corneal melt, impending perforation, or frank perforation secondary to the pathogen or likely related to the systemic disease indicated (except for patient 26, unknown aetiology).

ALK, anterior lamellar keratoplasty;DALK, deep anterior lamellar keratoplasty; KPro, Boston type 1 keratoprosthesis; LPG, lamellar patch graft; PK, penetrating keratoplasty.

\section{Surgery}

Surgeries were performed by a single surgeon at each respective location: Apollo Hospitals (RF, $n=6$ patients), Hospital de la Familia (ES, n=2 patients) and Johns
Hopkins Hospital (EKA, n=15 patients). Three types of surgery were performed using gamma-irradiated tissue: DALK/anterior lamellar keratoplasty (ALK), tectonic lamellar patch grafting and KPro implantation. Figure 1 
Table 2 Clinical outcomes of patients with non-inflammatory conditions undergoing anterior lamellar or full-thickness keratoplasty using gamma-irradiated corneal lenticules

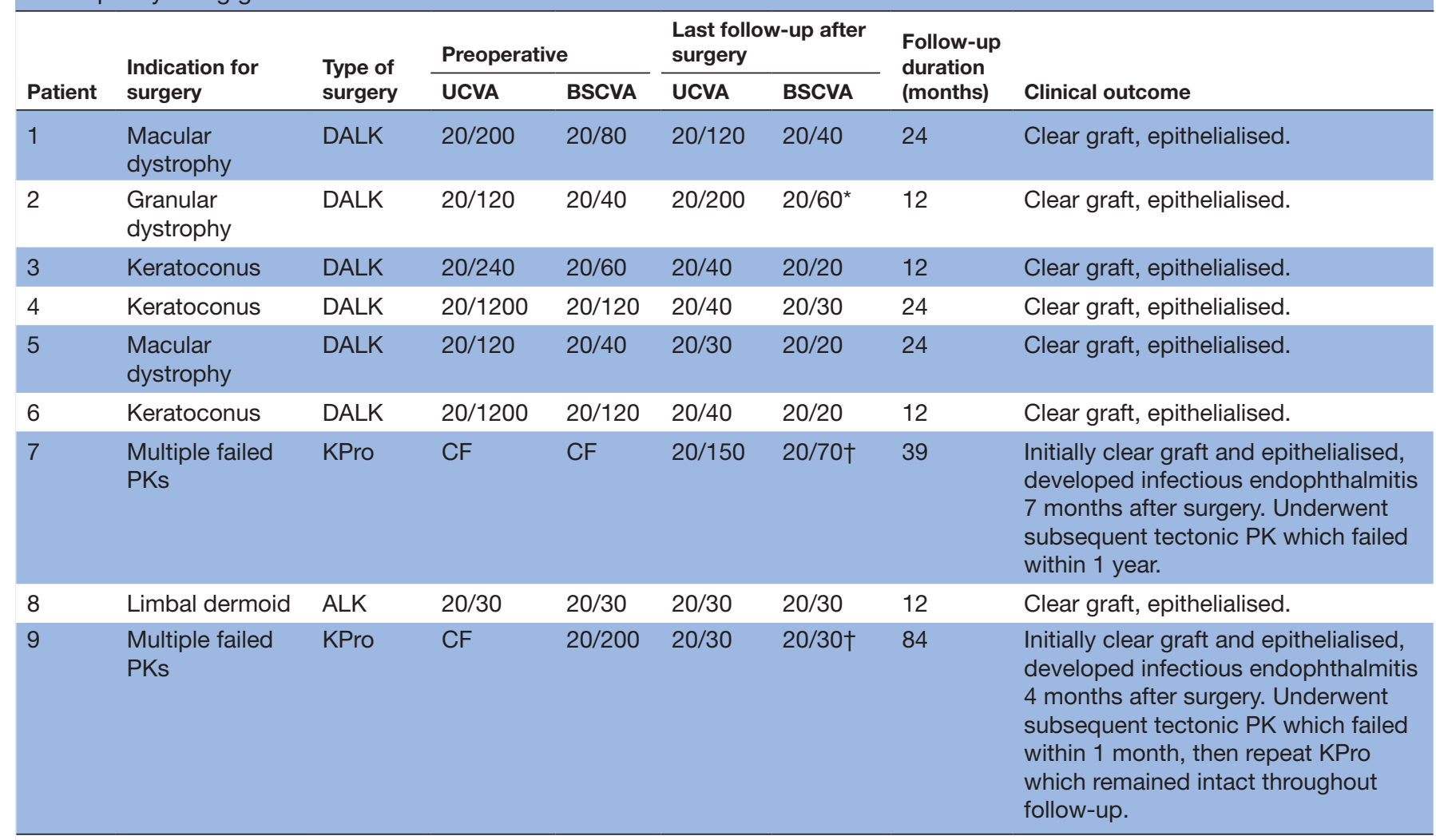

*Patient 2 had a recurrent presumed herpetic keratitis at month 6 and noted to have cataract at month 12. †Visual acuity reported is from the last follow-up visit after surgery but before onset of infection.

ALK, anterior lamellar keratoplasty; BSCVA, best spectacle-corrected visual acuity; CF, count fingers; DALK, deep anterior lamellar keratoplasty; KPro, Boston type 1 keratoprosthesis; PK, penetrating keratoplasty; UCVA, uncorrected visual acuity.

portrays the classification of patients by aetiology and type of surgery.

\section{Deep anterior lamellar keratoplasty}

A total of six patients (six eyes) underwent DALK with sterile cornea. The surgery was performed under general anaesthesia using the modified big bubble technique in three patients (two keratoconus and one granular dystrophy). ${ }^{15}$ The other three patients (two macular corneal dystrophy and one keratoconus with a deep corneal scar) underwent DALK using the manual technique. In general, the same graft size was used for patients with ectatic disorders, and the graft was oversized by 0.5 $\mathrm{mm}$ for other aetiologies. The donor size varied between 8.5 and $9.5 \mathrm{~mm}$ in diameter, and vision blue was applied after trephination to ensure that all remnants of the Descemet's membrane were identified and removed prior to transplantation. The graft was secured in the recipient cornea using either 16 interrupted or 16-bite running $10-0$ nylon sutures. The surgical video for patient 6 , who underwent DALK with sterile cornea using the modified big bubble technique, is available online (online supplementary video 1 ).

\section{ALK or lamellar patch graft}

Fifteen patients underwent ALK or lamellar patch graft with gamma-irradiated corneal tissue. ALK was performed for elective cases with no full-thickness corneal defect after removing the affected corneal tissue. Lamellar patch graft was performed as an emergency surgery in patients with a perforation secondary to infectious keratitis or inflammatory disease. The surgery was performed by first measuring the dimension of affected/diseased cornea to determine the size of host trephination. The host trephination was performed with a handheld trephine, taking necessary precautions to not disturb the intraocular contents. The donor tissue was oversized by 0.25 in all cases. The donor size varied between 4 and $6 \mathrm{~mm}$ in diameter. The graft was secured in the recipient cornea using multiple interrupted 10-0 nylon sutures.

\section{Boston type 1 keratoprosthesis}

Gamma-irradiated tissue was used as the donor tissue for KPro in two patients. The sterile cornea was already pretrephined with a diameter of $8.5 \mathrm{~mm}$. The KPro device (supplied by Massachusetts Eye and Ear Infirmary, Boston, Massachusetts, USA) was assembled with the sterile corneal tissue in the usual manner for keratoprosthesis surgery. The entire KPro device/donor tissue 


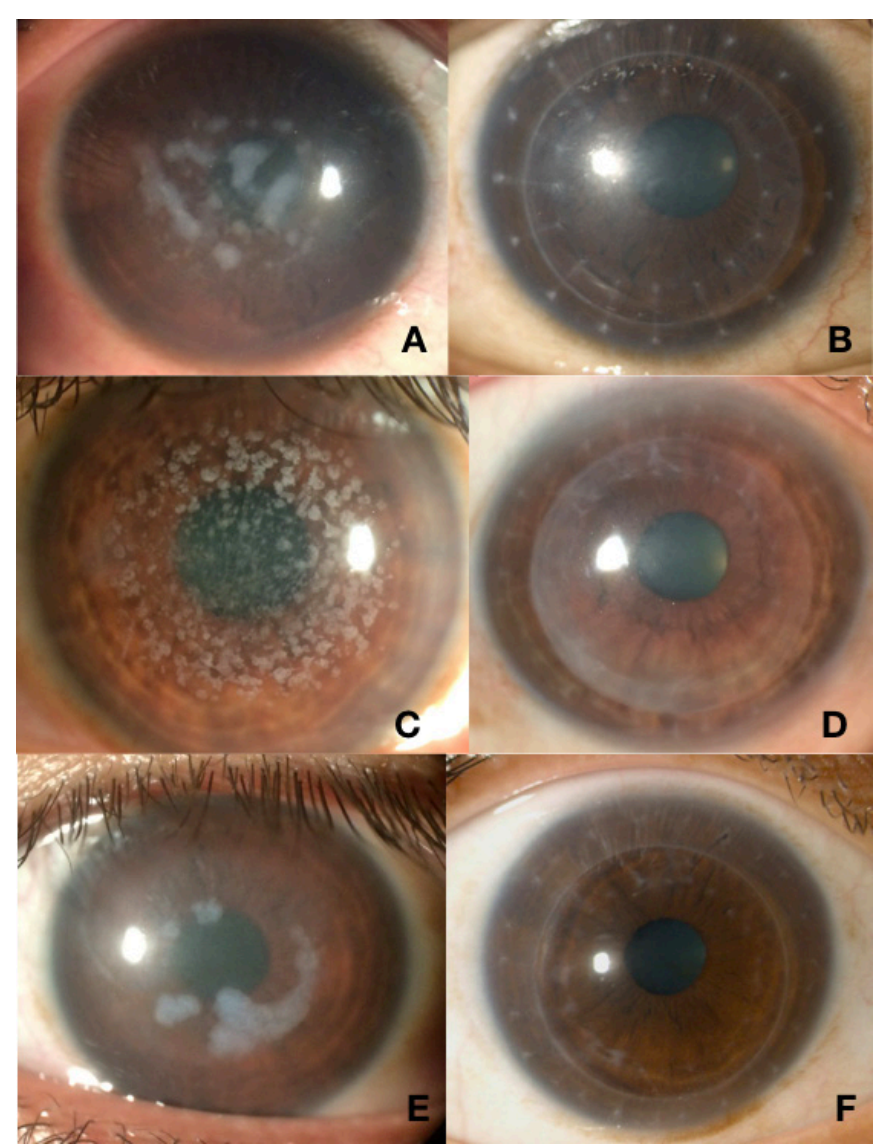

Figure 2 Preoperative and postoperative slit-lamp photos of three patients with stromal dystrophies undergoing deep anterior lamellar keratoplasty with gamma-irradiated corneal tissue. Patient 1 (macular dystrophy) before (A) and 1 month after (B) deep anterior lamellar keratoplasty. Patient 2 (granular dystrophy) before (C) and 1 month after (D) deep anterior lamellar keratoplasty. Patient 5 (macular dystrophy) before $(E)$ and 1 month after (F) deep anterior lamellar keratoplasty.

ensemble was sutured using 16 interrupted 10-0 nylon sutures in the same fashion as penetrating keratoplasty.

\section{Patient follow-up}

Postoperative medications were tailored to the aetiology of disease and type of surgery performed. After DALK/ ALK surgery, postoperative medications included topical prednisolone acetate $1 \%$ starting six times daily with a tapering regimen over 6 weeks, following which topical fluorometholone was continued twice a day for several months and discontinued. Topical moxifloxacin was used four times daily for the first week only until full epithelialisation of the graft, along with aggressive lubrication carboxymethylcellulose drops. After lamellar patch graft surgery, appropriate topical antimicrobials according to the infectious aetiology based on cultures or when not available clinical grounds were initiated immediately after surgery. Topical prednisolone acetate $1 \%$ was used only after an infection was ruled out or completely cleared (no infiltrate in the graft and complete epithelialisation). Patients with a history of autoimmune disease were given oral prednisone in addition to topical steroids (frequently with systemic non-steroidal immunosuppression). After KPro surgery, postoperative medications included topical prednisolone acetate $1 \%$ and moxifloxacin starting from four to eight times daily with a tapering regimen over 6-8 weeks. Daily antibiotic prophylaxis and topical steroids were maintained in KPro patients at doses dependent on the status of the eye (such as presence of glaucoma or ocular surface disease) and aetiology of disease.

Data from the regular follow-up examinations (postoperative day 1 , week 1, months 1, 3, 6 and 12, and annually thereafter at a minimum) were recorded and collected retrospectively. Postoperative measurements of interest included uncorrected visual acuity, pinhole visual acuity, intraocular pressure measurement using applanation tonometry, slit-lamp evaluation and dilated fundus examination. In addition, best spectacle-corrected visual acuity (BSCVA) and manual keratometry were recorded for all DALK patients. Patients with previous infectious or autoimmune aetiology were more frequently followed to watch for possible complications. Topical glaucoma medications were initiated if necessary to manage steroid-induced rise in the intraocular pressure. B-scan was performed whenever there was no view to the posterior segment. Patients with at least 5 months of follow-up after surgery were included in the data analysis, and all other patients were excluded.

\section{RESULTS}

Baseline demographics of the patients are described in table 1. Patients were categorised according to the aetiology of their corneal disease (ie, non-inflammatory, infectious keratitis and sterile keratolysis). Nine patients with non-inflammatory corneal conditions underwent either DALK $(n=6)$, ALK $(n=1)$ or KPro $(n=2)$. Eight patients with frank or impending perforation secondary to infectious keratitis had lamellar patch graft surgery. Six patients with autoimmune/inflammatory keratitis underwent tectonic lamellar patch graft surgery. All patients with infectious or inflammatory/autoimmune keratitis presented with either impending or frank corneal perforation with the exception of patient 23, who presented with a sterile inflammatory corneal lesion. The overall median follow-up duration was 24 months (range 5-105 months).

Table 2 depicts the clinical outcomes of the nine patients with non-inflammatory corneal conditions. In all nine cases, the graft remained intact and epithelialised during a median follow-up period of 24 months (range 12-84 months). In the seven cases undergoing lamellar keratoplasty (six DALK and one ALK), the grafts stayed optically clear over a median of 12 months (range 12-24 months). The two patients who had Boston type 1 KPro implantation initially did very well, with a significant improvement in visual acuity and fully epithelialised graft without any thinning during the first 3 months. However, both KPro patients developed endophthalmitis months between 4 and 7 months after the surgery, presumed to be unrelated 
Table 3 Clinical outcomes of patients with infectious keratitis undergoing lamellar patch graft surgery using gammairradiated corneal lenticules

\begin{tabular}{|c|c|c|c|c|c|c|}
\hline Patient & Age (years) & Sex & Indication for surgery & Histopathology & $\begin{array}{l}\text { Duration of } \\
\text { follow-up } \\
\text { (months) }\end{array}$ & Clinical outcome \\
\hline 10 & 43 & Female & $\begin{array}{l}\text { Presumed infectious } \\
\text { keratitis. }\end{array}$ & Not performed. & 6 & $\begin{array}{l}\text { Graft intact, epithelialised, } \\
\text { opacified. }\end{array}$ \\
\hline 11 & 47 & Male & $\begin{array}{l}\text { Presumed infectious } \\
\text { keratitis. }\end{array}$ & Not performed. & 6 & $\begin{array}{l}\text { Graft intact, epithelialised, } \\
\text { opacified. }\end{array}$ \\
\hline 13 & 65 & Male & Bacterial keratitis. & $\begin{array}{l}\text { Acute inflammatory } \\
\text { infiltrate and necrosis. }\end{array}$ & 5 & $\begin{array}{l}\text { Graft intact, epithelialised and } \\
\text { opacified. Underwent subsequent } \\
\text { optical PK with fresh tissue, which } \\
\text { also opacified. }\end{array}$ \\
\hline 14 & 48 & Female & $\begin{array}{l}\text { Presumed herpetic } \\
\text { keratitis. }\end{array}$ & $\begin{array}{l}\text { Acute inflammation } \\
\text { and necrosis. }\end{array}$ & 30 & $\begin{array}{l}\text { Graft intact, epithelialised and } \\
\text { clear. }\end{array}$ \\
\hline 16 & 51 & Female & $\begin{array}{l}\text { Presumed herpetic } \\
\text { keratitis with bacterial } \\
\text { superinfection. }\end{array}$ & $\begin{array}{l}\text { Acute inflammation } \\
\text { and necrosis. }\end{array}$ & 100 & $\begin{array}{l}\text { Graft intact, did not epithelialise, } \\
\text { developed fungal keratitis. } \\
\text { Underwent tectonic PK which } \\
\text { failed, and eventually conjunctival } \\
\text { flap performed. }\end{array}$ \\
\hline 17 & 80 & Female & $\begin{array}{l}\text { Presumed herpetic } \\
\text { keratitis with fungal } \\
\text { superinfection. }\end{array}$ & $\begin{array}{l}\text { Acute inflammation } \\
\text { and necrosis, fungal } \\
\text { elements. }\end{array}$ & 91 & $\begin{array}{l}\text { Graft intact, did not epithelialise } \\
\text { and cornea melted. Underwent } \\
\text { tectonic PK and KPro-both } \\
\text { failed, and eye eventually became } \\
\text { phthisical. }\end{array}$ \\
\hline
\end{tabular}

KPro, Boston type 1 keratoprosthesis; PK, penetrating keratoplasty.

to the corneal donor tissue used for the KPro because the cornea was not affected until later in the disease process. Patient 7 underwent removal of the device and tectonic penetrating keratoplasty. Pathological assessment of the removed corneal button revealed acute inflammation and necrosis with predominantly neutrophilic infiltrate and numerous Gram-positive cocci. The tectonic penetrating keratoplasty with fresh tissue eventually failed within a year but remained intact. Patient 9 developed endophthalmitis within 4 months after surgery, and vitreous tap was positive for staphylococcal species. She underwent removal of the device and tectonic penetrating keratoplasty, and pathological assessment revealed diffuse acute inflammatory infiltrate involving full thickness of stroma with area of necrosis, but did not identify any microbial elements. The graft failed in less than 1 month after surgery, and she developed retinal detachment 6 months after surgery. The patient underwent retinal detachment repair with repeat KPro, which has remained intact in the subsequent 6 years of follow-up.

In all of the DALK patients, complete corneal epithelialisation was noted on average at $6.6+/-1.3$ days after surgery (range 5-8 days). There were no postoperative complications and all grafts remained clear during the follow-up period of a median of 18 months (range 12-24 months). The BSCVA ranged from 20/20 to 20/40, with the exception of one patient (patient 2) having a final visual acuity of 20/60 due to a complicated postoperative course (an episode of epithelial keratitis presumed to be herpetic in origin and subsequent onset of age-related nuclear cataract). This patient was treated and maintained on oral antiviral therapy (acyclovir $400 \mathrm{mg}$ two times per day) to prevent further recurrences. Figure 2 is a compilation of the preoperative and postoperative slit-lamp photographs of three patients at the 12-month follow-up visit. 


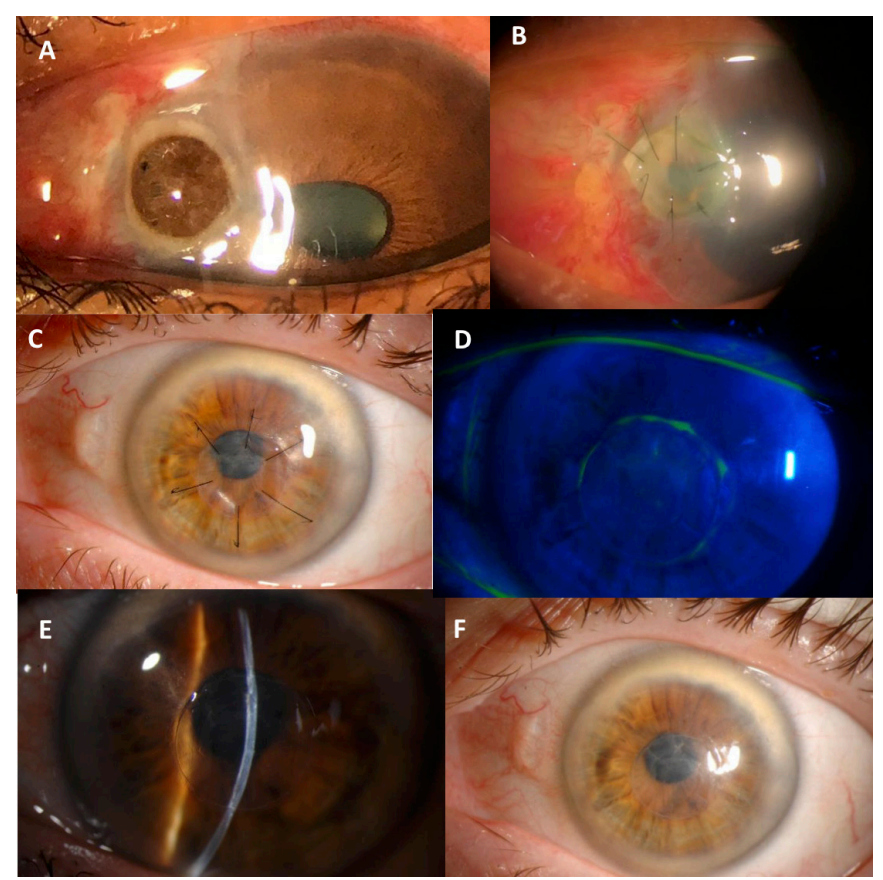

Figure 3 Slit-lamp photos of two patients with infectious keratitis undergoing lamellar patch graft surgery using gamma-irradiated corneal lenticules. Patient 11 with perforated infectious ulcer before surgery $(A)$ and 1 week after surgery (B). Patient 14 (perforation secondary to Herpes Simplex Virus corneal ulcer) 1 month after surgery $(C)$ and 3 months after surgery (D, E, F).

Table 3 lists the clinical outcomes of patients with infectious keratitis who underwent tectonic lamellar patch graft surgery. Six of the nine patients did very well, with the patch graft successfully restoring tectonic support until optical keratoplasty could be performed if decision was made to improve visual acuity. Three of the grafts did not epithelialise after surgery, two of which developed infectious corneal ulcers and one had sterile corneal melt (all between 1 and 3 months after surgery). All three had subsequent keratoplasty with fresh tissue and failed again in the two patients with follow-up data. Figure 3 shows slit-lamp photos of patients 11 and 14 before and after surgery.

Table 4 describes the clinical outcomes of patients with inflammatory or autoimmune-related corneal keratitis. Two of the patients had intact, epithelialised grafts at the last follow-up visit 8-29 months following surgery. One patient with rheumatoid arthritis and severe diabetic retinopathy (patient 20) initially epithelialised, however developed vitreoretinal complications soon after surgery. Remarkably, the graft remained intact throughout the follow-up period of 53 months even though the visual acuity was no light perception and the eye eventually became phthisical. Two patients (patients 19 and 21) had recurrent corneal melt within 3 months of surgery. Patient 19 underwent several tectonic penetrating keratoplasty (all with fresh tissue) until adequate immunosuppression was achieved a few months after surgery, and eventually the last graft epithelialised, scarred and vascularised. Patient 21 underwent subsequent KPro implantation which also failed 6 months after surgery, and eventually the cornea scarred and KPro was left in place. Both patients 19 and 21 deferred any additional surgical intervention after their last graft opacified and remained intact. Figure 4 shows slit-lamp photos of patients 21 and 23 before and after surgery.

\section{DISCUSSION}

This multicentre, retrospective interventional case series demonstrates that gamma-irradiated corneal lenticules can be used for a variety of corneal diseases and types of surgery, in both emergency and elective settings. Sterile corneal tissue is an excellent option to temporise the eye in the setting of infectious keratitis or sterile keratolysis until the infection can be completely eradicated or adequate systemic immunosuppression is achieved. Additionally, the patients with anterior corneal disease and healthy endothelium achieved excellent visual outcomes. There were no complications specifically attributable to the donor in any of the patients during the follow-up period.

Currently, the single, most limiting factor to cure corneal blindness is the significant shortage of donor tissues, with only one cornea available for every 70 patients who are in need. ${ }^{3}$ Unlike in USA where Fuchs endothelial dystrophy is prevalent, in developing countries the leading causes of corneal blindness are infectious keratitis or trauma with anterior stromal scarring. ${ }^{17} 18$ It is important to recognise that an estimated $98 \%$ of bilateral corneal blindness occurs outside of developed countries and involves the anterior layers of the stroma. ${ }^{19}$ The surgery for these conditions requires transplantation of only stromal layer since the endothelium is commonly healthy. The gammairradiated corneal lenticules may be an excellent option for these cases. The tissues are terminally sterilised and have a shelf-life of 2 years at room temperature eliminating the costly distribution or storage conditions that fresh tissues require.

Multiple preclinical studies have recognised sterile corneal allograft as a suitable alternative and potentially optically superior option for procedures that do not require a healthy donor endothelial layer. ${ }^{6} 1013{ }^{20}$ In fact sterile corneas may provide better visual acuity for anterior lamellar procedures due to a smoother interface than do fresh tissues for laser-assisted lamellar anterior keratoplasty. ${ }^{21}$ Wee et $a l^{22}$ reported excellent outcomes when using the combination of irradiated acellular cornea with amniotic membrane transplantation (AMT) in patients with intractable ocular surface diseases. They noted that AMT facilitated epithelial healing, and ultimately better graft survival. Indeed, we observed that our cases with delayed or lack of epithelial healing were more likely to fail, suggesting that simultaneous AMT may be beneficial in high-risk cases (similar to conventionally prepared fresh corneas). Additionally, gamma irradiation reduces the allogenicity of these corneas, thereby reducing the risk of immunological sensitisation of the 
Table 4 Clinical outcomes of patients with inflammatory or autoimmune keratitis undergoing lamellar patch graft surgery using gamma-irradiated corneal lenticules

\begin{tabular}{|c|c|c|c|c|c|c|}
\hline Patient & $\begin{array}{l}\text { Age } \\
\text { (years) }\end{array}$ & Sex & Indication for surgery & Histopathology & $\begin{array}{l}\text { Duration of } \\
\text { follow-up } \\
\text { (months) }\end{array}$ & Clinical outcome \\
\hline 19 & 80 & Female & $\begin{array}{l}\text { Systemic lupus } \\
\text { erythematosus with } \\
\text { secondary Sjögren's } \\
\text { syndrome. }\end{array}$ & $\begin{array}{l}\text { Acute inflammation and } \\
\text { necrosis, no e/o infection. }\end{array}$ & 96 & $\begin{array}{l}\text { Never epithelialised, graft melted } \\
<1 \text { month. Underwent several } \\
\text { subsequent tectonic PKs -all } \\
\text { melted. Eventually cornea } \\
\text { epithelialised, scarred and } \\
\text { vascularised after achieving } \\
\text { adequate immunosuppression. }\end{array}$ \\
\hline 20 & 81 & Female & Rheumatoid arthritis. & $\begin{array}{l}\text { Acute inflammation and } \\
\text { necrosis, no e/o infection. }\end{array}$ & 53 & $\begin{array}{l}\text { Graft intact and epithelialised, } \\
\text { but developed other intraocular } \\
\text { complications due to retinal } \\
\text { surgery. Eventually eye became } \\
\text { phthisical. }\end{array}$ \\
\hline 22 & 75 & Female & $\begin{array}{l}\text { Sterile keratolysis } \\
\text { with unknown } \\
\text { aetiology. }\end{array}$ & $\begin{array}{l}\text { Acute inflammation and } \\
\text { necrosis, no e/o infection. }\end{array}$ & 29 & $\begin{array}{l}\text { Graft intact, epithelialised and } \\
\text { remained clear. }\end{array}$ \\
\hline 23 & 13 & Female & $\begin{array}{l}\text { Sterile inflammatory } \\
\text { corneal lesion with } \\
\text { unknown aetiology. }\end{array}$ & $\begin{array}{l}\text { Stromal } \\
\text { lymphoplasmacytic } \\
\text { inflammation with } \\
\text { granulomatous features. }\end{array}$ & 8 & $\begin{array}{l}\text { Graft intact, epithelialised and } \\
\text { remained clear. }\end{array}$ \\
\hline
\end{tabular}

e/o, evidence of; KPro, Boston type 1 keratoprosthesis; PK, penetrating keratoplasty.

host or rejection. ${ }^{13}$ Therefore, gamma-irradiated tissue may be better option to temporise the eye in the setting of emergency for a tectonic procedure, and preserve vision potential for future surgery. Indeed a recent retrospective study examining the results of emergent keratoplasty performed for combat injury in US military patients serving in Iraq or Afghanistan reported a graft failure rate of over $30 \%$ within the first year after surgery. ${ }^{23}$ Although major developed cities around the world may have access to an eye bank, a significant proportion in the USA and the world does not have access to obtaining fresh corneal tissue in less than 24 hours.

Limitations of this study include the small number of patients and lack of follow-up data. Additionally, other objective corneal findings would be helpful, such as specular biomicroscopy, automated topography and confocal biomicroscopy, particularly in patients who underwent optical procedures. Nevertheless, we believe our results are an important addition to the current scope of knowledge and will hopefully encourage greater utilisation of this corneal tissue.

In conclusion, availability of the tissues is a step towards curing worldwide corneal blindness, especially in areas with greatest demand. Promoting advanced surgical training in less developed countries is another critical component. Lastly, continuing to explore alternatives, such as artificial corneal devices, to eliminate the need for donor corneal transplantation altogether should be the ultimate goal.

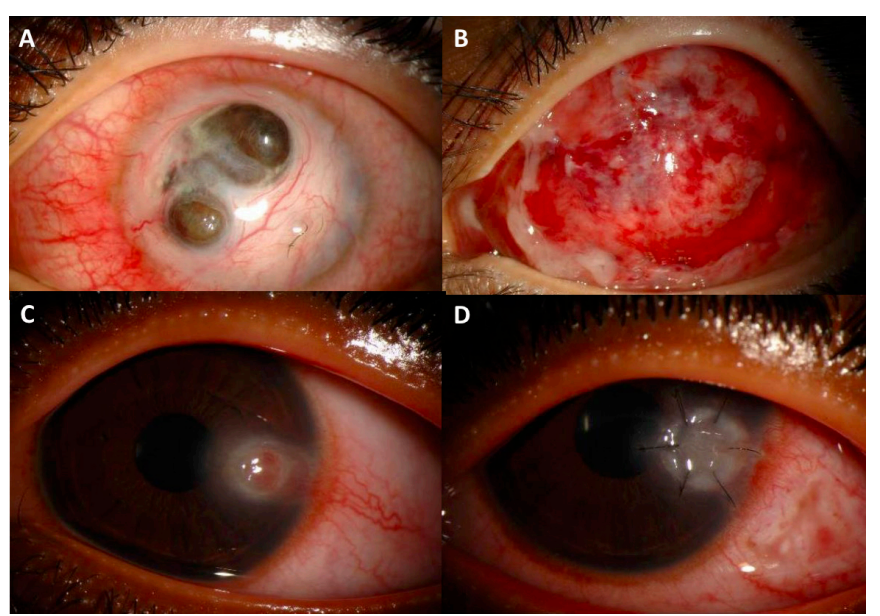

Figure 4 Slit-lamp photos of two patients with autoimmune/ inflammatory keratitis undergoing lamellar patch graft surgery using gamma-irradiated corneal lenticules. Patient 21 before surgery $(A)$ and 1 month after anterior lamellar keratoplasty done with conjunctival flap (B). Patient 23 before surgery (C) and 1 month after anterior lamellar keratoplasty (D). 
Contributors PMM, EKA: design of the work, acquisition/analysis/interpretation of data, revising the manuscript, final approval of version to be published and agree to be accountable for all aspects of the work. RF, ES, SV: acquisition/analysis/ interpretation of data, revising the manuscript, final approval of version to be published and agree to be accountable for all aspects of the work.

Funding KeraLink International donated the gamma-irradiated corneal tissue to Hospital de la Familia, Guatemala and Apollo Hospitals, Hyderabad, India.

Competing interests PMM: WL Gore \& Associates: consultant/advisor. EKA: Allergan, WL Gore \& Associates: institutional grant support; CorneaGen and KeraLink: medical director; Novaliq, Clementia, Novartis Pharma AG, Shire, EpiTech, Takeda: consultant/advisor; Dompe: ad board; Sjogren's Syndrome Foundation: unpaid member of the Board of Directors; Up-To-Date: royalty.

Patient consent for publication Not required.

Ethics approval This multicentre, interventional retrospective case series was approved by the Institutional Review Board of Apollo Hospitals (India), the Ethics Committee of Hospital de la Familia (Guatemala) and the Institutional Review Board of Johns Hopkins University (USA). The Johns Hopkins University Institutional Review Board also approved for remote data analysis and interpretation of the de-identified information of the patients included from India and Guatemala. The study was conducted in accordance with the Declaration of Helsinki and adhered to the Health Insurance Portability and Accountability Act. It was not possible to involve patients or the public in the design, conduct, reporting or dissemination of our research. Informed consent was obtained according to institutional requirements.

Provenance and peer review Not commissioned; internally peer reviewed.

Open access This is an open access article distributed in accordance with the Creative Commons Attribution Non Commercial (CC BY-NC 4.0) license, which permits others to distribute, remix, adapt, build upon this work non-commercially, and license their derivative works on different terms, provided the original work is properly cited, appropriate credit is given, any changes made indicated, and the use is non-commercial. See: http://creativecommons.org/licenses/by-nc/4.0/.

ORCID iD

Esen K Akpek http://orcid.org/0000-0001-7700-207X

\section{REFERENCES}

1 Resnikoff S, Pascolini D, Etya'ale D, et al. Global data on visual impairment in the year 2002. Bull World Health Organ 2004;82:844-51.

2 Pascolini D, Mariotti SP. Global estimates of visual impairment: 2010. Br J Ophthalmol 2012;96:614-8.

3 Gain P, Jullienne R, He Z, et al. Global survey of corneal transplantation and eye banking. JAMA Ophthalmol 2016;134:167-73.

4 Krader CG. Cornea allograft provides alternative. Ophthalmology Times 2011.
5 Utine CA, Tzu JH, Akpek EK. Lamellar keratoplasty using gammairradiated corneal lenticules. Am J Ophthalmol 2011;151:170-4.

6 Calhoun WR, Akpek EK, Weiblinger R, et al. Evaluation of broadband spectral transmission characteristics of fresh and gamma-irradiated corneal tissues. Cornea 2015;34:228-34.

7 Pan Q, Jampel HD, Ramulu P, et al. Clinical outcomes of gammairradiated sterile cornea in aqueous drainage device surgery: a multicenter retrospective study. Eye (Lond) 2017;31:430-6.

8 Akpek EK, Aldave AJ, Aquavella JV. The use of precut, $\gamma$-irradiated corneal lenticules in Boston type 1 keratoprosthesis implantation. Am J Ophthalmol 2012;154:e491:495-8.

9 Fadlallah A, Atallah M, Cherfan G, et al. Gamma-Irradiated corneas as carriers for the Boston type 1 keratoprosthesis: advantages and outcomes in a surgical mission setting. Cornea 2014;33:235-9.

10 Sikder S, McCally RL, Engler C, et al. Evaluation of irradiated corneas using scatterometry and light and electron microscopy. Cornea 2011;30:503-7.

11 Chae JJ, Choi JS, Lee JD, et al. Physical and biological characterization of the gamma-irradiated human cornea. Cornea 2015;34:1287-94.

12 Daoud YJ, Smith R, Smith T, et al. The intraoperative impression and postoperative outcomes of gamma-irradiated corneas in corneal and glaucoma patch surgery. Cornea 2011;30:1387-91.

13 Stevenson W, Cheng S-F, Emami-Naeini P, et al. Gamma-Irradiation reduces the allogenicity of donor corneas. Invest Ophthalmol Vis Sci 2012:53:7151-8.

14 Arafat SN, Robert M-C, Shukla AN, et al. UV cross-linking of donor corneas confers resistance to keratolysis. Cornea 2014;33:955-9.

15 Fogla R, Padmanabhan P. Results of deep lamellar keratoplasty using the big-bubble technique in patients with keratoconus. Am J Ophthalmol 2006:141:254-9.

16 Fontana L, Parente G, Tassinari G. Clinical outcomes after deep anterior lamellar keratoplasty using the big-bubble technique in patients with keratoconus. Am J Ophthalmol 2007;143:117-24.

17 Mathews PM, Lindsley K, Aldave AJ, et al. Etiology of global corneal blindness and current practices of corneal transplantation: a focused review. Cornea 2018;37:1198-203.

18 Garg P, Krishna PV, Stratis AK, et al. The value of corneal transplantation in reducing blindness. Eye (Lond) 2005;19:1106-14

19 Oliva MS, Schottman T, Gulati M. Turning the tide of corneal blindness. Indian J Ophthalmol 2012;60:423-7.

20 Yoshida J, Heflin T, Zambrano A, et al. Gamma-Irradiated sterile cornea for use in corneal transplants in a rabbit model. Middle East Afr J Ophthalmol 2015;22:346-51.

21 Zhang X, Igo RP, Fondran J, et al. Association of smoking and other risk factors with Fuchs' endothelial corneal dystrophy severity and corneal thickness. Invest Ophthalmol Vis Sci 2013;54:5829-35.

22 Wee SW, Choi SU, Kim JC. Deep anterior lamellar keratoplasty using irradiated acellular cornea with amniotic membrane transplantation for intractable ocular surface diseases. Korean J Ophthalmol 2015;29:79-85.

23 Vlasov A, Ryan DS, Ludlow S, et al. Corneal and corneoscleral injury in combat ocular trauma from operations Iraqi freedom and enduring freedom. Mil Med 2017;182:114-9. 